JURNAL TABULARASA PPS UNIMED, VOI.15 No.1, April 2018

p-ISSN: 1693-7732, e-ISSN: 2502-7247

http://jurnal.unimed.ac.id/2012/index.php/tabularasa

\title{
Peningkatan Hasil Belajar PKn Melalui Metode Card Sort pada Siswa SD Negeri 050748 Pangkalan Berandan Tahun Ajaran 2016-2017
}

\author{
Nilam Sari \\ SD Negeri 050748 Pangkalan Berandan Sumatera Utara Indonesia \\ Email: nilamsari@gmail.com
}

\begin{abstract}
Abstrak
Tujuan penelitian ini adalah untuk meningkatkan hasil belajar PKn melalui metode Card Sort pada siswa SD Negeri 050748 Pangkalan Berandan Tahun Ajaran 2016/2017. Penelitian ini merupakan penelitian tindakan kelas dengan metode penelitian deskriptif kualitatif yang terdiri dari 2 siklus. Dari hasil penelitian dapat diketahui bahwa dengan menggunakan metode Card Sort hasil belajar siswa mengalami peningkatan disetiap siklusnya. Hal itu dapat dilihat dari perolehan data pada siklus I yang nilai rata-ratanya mencapai 70,47 dengan persentase ketuntasan mencapai 61,90\%. Dan pada siklus II nilai rata-rata mencapai 81,42 dengan persentase ketuntasan mencapai $85,71 \%$. Hal ini menunjukkan bahwa siswa lebih paham mengikuti pembelajaran PKn dengan menggunakan metode Card Sort. Ini dapat disimpulkan bahwa dengan menggunakan metode Card Sort dapat meningkatkan hasil belajar PKn siswa.
\end{abstract}

Kata Kunci: Hasil Belajar, Metode Card Sort, Penelitian Tindakan Kelas

\begin{abstract}
The purpose of this study is to improve the students learning outcomes through Card Sort method on the students of SD Negeri 050748 Pangkalan Berandan year 2016/2017. This research is a classroom action research with qualitative descriptive research consisting of 2 cycles. From the research results can be seen that by using the Card Sort method, student's learning outcomes have increased in each cycle. It can be seen from the data acquisition in the first cycle that the average value reached 70.47 with the percentage of completeness reached $61.90 \%$. And then, in cycle II, the average value of student's learning outcomes reached 81.42 with the percentage of completeness
\end{abstract}


reached $85.71 \%$. This indicates that the students are more aware to follow the students learning outcome by using Card Sort method. It can be concluded that using the Card Sort method can improve student learning outcomes.

Keywords: Learning Outcomes, Card Sort Methods, Classroom Action Research

\section{A. PENDAhULUAN}

Proses pendidikan di Indonesia seharusnya ada keterkaitan antara pendukung dari segala aspek yang mempengaruhi pendidikan yang diantaranya dapat dilihat dari aspek guru, siswa, keluarga maupun pemerintah haruslah berperan aktif agar tujuan pendidikan nasional dapat tercapai. Seperti halnya kurikulum yang diaplikasikan pada proses pendidikan di Indonesia seperti yang diungkapkan dalam Undang-undang Sistem Pendidikan Nasional (UU Sisdiknas) No. 20 tahun 2003 pasal 27.

Mata pelajaran PKn sangatlah penting untuk diberikan kepada siswa untuk semua jenjang pendidikan agar siswa dapat memiliki kemampuan berpikir kritis, rasional, dan kreatif dalam menangggapi isu-isu kewarganegaraan (Permendiknas 2006). Pendidikan Kewarganegaraan (PKn) merupakan salah satu mata pelajaran yang dapat meningkatkan kualitas Sumber Daya Manusia (SDM), karena dalam mata pelajaran PKn terdapat materi tentang nilai moral yang penting untuk kemajuan SDM. PKn sendiri adalah mata pelajaran yang di gunakan sebagai wahana untuk mengembangkan dan melestarikan nilai luhur dan moral yang berakar pada budaya bangsa Indonesia. Nilai luhur dan moral ini di harapkan dapat di wujudkan dalam bentuk perilaku kehidupan siswa sehari-hari, baik sebagai individu maupun anggota masyarakat, dan makhluk ciptaan Tuhan Yang Maha Esa, yang merupakan usaha untuk membekali siswa dengan pengetahuan dan kemampuan dasarberkenaan dengan hubungan antar warga dengan negara serta pendidikanpendahuluan bela negara agar menjadi warga negara yang dapat diandalkan oleh bangsa dan negara.

Berdasarkan hasil observasi yang dilakukan di kelas V-ASD Negeri 050748 Pangkalan Berandan ditemukan bahwa kemampuan siswa dalam menguasai mata pelajaran PKn tergolong rendah. Hal ini 
dapat dilihat dari kriteria ketuntasan mengajar yang diterapakan untuk mata pelajaran PKn adalah 75. Dari hasil survei diketahui bahwa dari sejumlah 18 siswa, 6 siswa memperoleh nilai sesuai KKM dan 12 siswa yanglain belum memenuhi KKM yang ditentukan. Masih banyak guruyang menggunakan metode konvensional secara monoton dalam kegiatan pembelajaran di kelas, sehingga suasana belajar terkesan kaku dan di dominasi oleh seorang guru. Hal ini berdampak pada rendahnya prestasi belajar siswa. Dampak ini dapat diatasi dengan pemilihan metode yang tepat dan sesuai dengan materi yang akan di sampaikan. Salah satu metode yang tepat untuk mata pelajaran PKn adalah metode Card Sort.

Metode Card Sort adalah suatu kegiatan kolaboratif yang bisa di gunakan untuk mengajar konsep, karakteristik klasifikasi, fakta tentang obyek atau mereviewinformasi. Gerakan fisik yang dominan dalam strategi ini dapat membantu mendinamisir kelas yang jenuh atau bosan. Dengan metode tersebut siswa dituntut untuk lebih aktif, berfikir cepat dan tepat.

Pada artikel ini, peneliti akan menjawab bagaimana cara meningkatkan prestasi belajar PKn melalui metode card sort pada siswa SD Negeri 050748 Pangkalan Berandan Tahun Pelajaran 20162017

\section{B. TINJAUAN PUSTAKA}

\section{Pengertian Prestasi Belajar}

Belajar dapat di pahami sebagai tahapan perubahan tingkah laku individu yang relatif menetap sebagai hasil pengalaman dan interaksi dengan lingkungan yang melibatkan proses kognitif sedangkan menurut Sutikno (2014: 180) Belajar adalah suatu proses usaha yang di lakukan seseorang untuk memperoleh suatu perubahan yang baru, sebagai hasil pengalamannya sendiri dalam interaksi dengan lingkungannya. Belajar secara psikologis merupakan suatu proses perubahan yaitu perubahan tingkah laku sebagai hasil dari interaksi dengan lingkungannya dalam memenuhi kebutuhan hidupnya (Slameto, 1991: 2)

Dari ketiga definisi di atas dapat di simpulkan bahwa belajar itu senantiasa merupakan perubahan tingkah laku atau penampilan, dengan serangkaian kegiatan misalnya dengan membaca, mengamati, mendengarkan, meniru dan lain sebagainya. Belajar akan lebih baik 
jika subjek belajar itu mengalami atau melakukannya. Belajar sebagai kegiatan individu yang di kirim kepadanya oleh lingkungan. Dengan demikian terjadinya kegiatan belajar yang dilakukan oleh seorang individu dapat dijelaskan dengan rumus antara individu dengan lingkungan.

Kata Prestasi berasal dari bahasa Belanda yaitu prestatie. Kemudian dalam bahasa Indonesia menjadi Prestasiyang berarti hasil usaha. Prestasi belajar adalah suatu masalah yang bersifat perenial dalam sejarah kehidupan manusia karena sepanjang rentang kehidupannya manusia selalu mengejar prestasi menurut bidang dan kemampuan masing-masing. Prestasi belajar merupakan hasil belajar yang di peroleh atau dicapai oleh siswa setelah mengikuti proses belajar mengajar dalam kurun waktu tertentu. Bentuk konkrit dalam prestasi belajar adalah dalam bentuk skor akhir dari evaluasi yang di masukkan dalam nilai raport. Untuk mengetahui prestasi belajar siswa di lakukan evaluasi.

Prestasi belajar merupakan wujud yang menggambarkan usaha belajar yang melibatkan interaksi antara guru dan siswa, ataupun orang lain dan lingkungannya. Dari pengertian ini dapat di katakan bahwa prestasi belajar adalah hasil yang di capai siswa setelah melalui proses belajar yang ditunjukkan dalam bentuk angka, huruf ataupun tindakan yang mencerminkan prestasi anak dalam prestasi tertentu. Prestasi berhubungan erat dengan penguasaan seseorang mengenai sesuatu hal yang mencerminkan berhasil atau gagal dalam sering di gunakan istilah prestasi. Prestasi biasanya di lambangkan dalam bentuk nilai yang berwujud angka atau huruf.

\section{Fungsi Utama Prestasi Belajar}

Adapun fungsi utama dari prestasi belajar adalah:

a. Prestasi belajar sebagai indikator kualitas dan kuantitas pengetahuan yang telah di kuasai anak didik.

b. Prestasi belajar sebagai lambang pemuasan hasrat ingin tahu.

c. Prestasi belajar sebagai bahan informasi dalam inovasi pendidikan.

d. Prestasi belajar sebagai indikator intern dan ekstern dari suatu institusi pendidikan.

e. Prestasi belajar dapat di jadikan indikator terhadap daya serap (kecerdasan) anak didik. 


\section{Faktor-Faktor Yang Mempengaruhi Prestasi Belajar}

Belajar merupakan proses menimbulkan terjadinya perubahan atau pembaharuan dalam tingkahlaku. Jadi berhasil tidaknya seseorang dalamproses belajar tergantung dari faktor-faktor yang mempengaruhinya. Menurut Syah (2010: 145-157) dalam bukunya Psikologi Belajar mengemukakan bahwa faktor-faktor yang mempengaruhi belajar siswa dapat di bedakan menajadi tiga macam, yaitu faktor internal, factor eksternal dan faktor pendekatan belajar.

\section{a. Faktor internal siswa}

Faktor yang berasal dari dalam diri siswa sendiri meliputi dua aspek.

1. Aspek fisiologis (faktor jasmaniah)

Kondisi umum jasmaniah dan tonus (tegangan otot) yang menandai tingkat kebugaran organ-organ tubuh dan sendi-sendinya, dapat mempengaruhi semangat dan intensitas siswa dalam mengikuti pelajaran. Kondisi organ-organ khusus siswa, seperti tingkat kesehatan indera pendengaran dan indera penglihatan, juga sangat mempengaruhi kemampuan siswa dalam menyerap informasi dan pengetahuan, khususnya yang di sajikan di kelas.

2. Faktor Psikologis

Faktor-faktor rohaniah siswa yang pada umumnya dipandang lebih esensial itu adalah sebagai berikut.

\section{- Tingkat Kecerdasan/Intelegensi Siswa}

Tingkat kecerdasan/ intelegensi (IQ) siswa tak dapat diragukan lagi, sangat menentukan keberhasilan belajar siswa.Ini bermakna, semakin tinggi kemampuan intelegensi seorangsiswa maka semakin besar untuk meraih sukses. Sebaliknya, semakin rendah tingkat intelegensi seorang siswa makasemakin kecil peluangnya untuk memperoleh sukses.

\section{- Sikap Siswa}

Sikap adalah segala internal yang berdimensi efektifberupa kecenderungan untuk mereaksi atau meresponsdengan cara yang relatif tetap terhadap objek orang, barang,dan sebagainya, baik secara positif maupun negatif.

\section{- Bakat Siswa}

Secara umum, bakat adalah kemampuan potensial yang dimiliki seseorang untuk mencapai keberhasilan pada masayang akan 
datang. Dengan demikian, sebetulnya setiap orang parsti memilikibakat dalam arti berpotensi untuk mencapai prestasi sampaike tingkat tertentu sesuai dengan kapasitas masing-masing.

\section{- Minat Siswa}

Secara sederhana minat berarti kecenderungan dankegairahan yang tinggi atau keinginan yang besar terhadapsesuatu.

\section{- Motivasi Siswa}

Pengertian dasar motivasi ialah keadaan internalorganisme baik manusia ataupun hewan yang mendorongnyauntuk berbuat sesuatu. Dalam pengertian ini motivasi berartipemasok daya untuk bertingkah laku secara terarah.

\section{b. Faktor Eksternal Siswa}

Seperti faktor internal siswa, faktor eksternal siswa juga terdiriatas dua macam.

\section{Lingkungan social}

Lingkungan sosial sekolah seperti para guru, para staf administrasi, dan teman-teman sekelasnya dapat mempengaruhi semangat belajar seorang siswa. Para guru yang selalu menunjukkan sikap dan perilaku yang simpatik dan memperlihatkan suri teladan yang baik dan rajin khususnya dalam hal belajar, misalnya rajin membaca dan berdiskusi, dapat menjadikan daya dorong yang positif bagi kegiatan belajar siswa. Selanjutnya, yang termasuk lingkungan sosial siswa adalah masyarakat dan tetangga juga teman-teman sepermainan di sekitar perkampungan siswa tersebut. Kondisi masyarakat dilingkungan kumuh yang serba kekurangan dan anak-anak pengangguran, misalnya, akan sangat mempengaruhi aktifitas belajar siswa. Paling tidak, siswa tersebut akan menemukan kesulitan ketika memerlukan teman belajar atau berdiskusi atau meminjam alatalat belajar tertentu yang kebetulan belum dimilikinya. Lingkungan sosial yang lebih banyak mempengaruhi kegiatan belajar ialah orang tua dan keluarga siswa itu sendiri. Sifat-sifat orang tua, praktik pengelolaan keluarga, ketegangan keluarga, dan demografi keluarga (letak rumah), semuanya dapatmemberi dampak baik ataupun buruk terhadap kegiatan belajardan hasil yang dicapai oleh siswa. 


\section{Lingkungan Non-sosial}

Faktor-faktor yang termasuk lingkungan nonsosial ialahgedung sekolah dan letaknya, rumah tempat tinggal keluarga siswa dan letaknya, alat-alat belajar, keadaan cuaca dan waktu belajar yang digunakan siswa. Faktor-faktor ini di pandang turuttingkat keberhasilan belajar siswa. Rumah yang sempit dan berantakan serta perkampungan yang terlalu padat dan tak memiliki sarana umum untuk kegiatanremaja akan mendorong siswa untuk berkeliaran ke tempat-tempat yang sebenarnya tak pantas di kunjungi. Kondisi rumah dan perkampungan seperti itu jelas berpengaruh buruk terhadap kegiatan belajar siswa.

\section{c. Faktor Pendekatan Belajar}

Pendekatan belajar dapat di pahami sebagai segala cara ataustrategi yang di gunakan siswa dalam manunjang keefektifan danefesiensi proses pembelajaran materi tertentu. Faktor pendekatanbelajar juga berpengaruh terhadap taraf keberhasilan proses belajarsiswa tersebut.

\section{Prinsip-Prinsip Belajar}

Menurut Slameto (1991: 29) prinsip-prinsip belajar ada beberapa macamyaitu sebagai berikut.

a. Dalam belajar setiap siswa harus di usahakan partisipasi aktif, meningkatkan minat dan membimbing untuk mencapai tujuan instruksional.

b. Belajar bersifat keseluruhan dan materi itu harus memiliki struktur, penyajian yang sederhana, sehingga siswa mudah menangkap pengertiannya.

c. Belajar harus dapat menimbulkan reinforcement dan motivasi yang kuat pada siswa untuk mencapai tujuan instruksional.

d. Belajar itu proses kontinyu, maka harus tahap demi tahap menurut perkembangannya.

e. Belajar adalah proses organisasi, adaptasi, eksplorasi dan discovery.

f. Belajar harus dapat mengembangkan kemampuan tertentu sesuai dengantujuan instruksional yang harus di capainya.

g. Belajar memerlukan sarana yang cukup sehingga siswa dapat belajar dengan tenang. 
h. Belajar perlu lingkungan yang menantang dimana anak dapat mengembangkan kemampuannya bereksplorasi dan belajar dengan efektif.

i. Belajar perlu ada interaksi siswa dengan lingkungannya.

j. Belajar adalah proses kontiguitas (hubungan antara pengertian yang satudengan pengertian yang lain) sehingga mendapatkan pengertian yang diharapkan. Stimulus yang diberikan menimbulkan response yang diharapkan.

k. Repetisi, dalam proses belajar perlu ulangan berkali-kali agarpengertian/keterampilan/sikap itu mendalam pada siswa.

\section{Metode Card Sort}

Metode Card Sort sebagai salah satu cara yang menyenangkan dan mengaktifkan siswa untuk meninjau ulang materi yang telah di sampaikan sebelumnya. Dalam Sutikno (2014: 130-131), metode mensortir kartu ini (Card Sort) di gunakan oleh peserta didik dengan maksud mengajak peserta didik untuk menemukan konsep dan fakta melalui klasifikasi materi yang di bahas dalam pembelajaran. Tujuan dari metode mensortir kartu ini adalah untuk mengungkapkan daya ingat terhadap materi pelajaran yeng telah di pelajari siswa.

\section{Langkah-langkah Metode Card Sort}

Langkah-langkah dalam penerapannya sebagai berikut:

a. Bagi kelas ke dalam beberapa kelompok.

b. Bagikan kertas plano yang telah di beri tulisan kata kunci atau informasi tertentu atau kategori tertentu secara acak kepada setiap kelompok. Pada tempat yang terpisah, letakkan kartu warna-warni yang berisi jawaban/ informasi yang tepat untuk masing-masing kata kunci. Buatlah kartu-kartu itu tercampur aduk.

c. Mintalah setiap kelompok mencari kartu yang cocok dengan kata kunci tersebut. Jelaskan kepada setiap kelompok bahwa kegiatan ini merupakan latihan pencocokan.

d. Setelah mereka menemukan kartu yang cocok, mintalah mereka menempelkan ke lembar kata kunci sehingga menjadi sebuah informasi.

e. Pendidik memberi tanggapan terhadap jawaban peserta didik.

f. Simpulkan. 
Ada beberapa perlengkapan yang harus di siapkan guru sebelumpelaksanaan pembelajaran, di antaranya adalah: potongan kertas karton berbentuk kartu berukuran $\pm 10 \mathrm{~cm}$ x 15 sebanyak jumlah peserta didik dikelas. Alat perekat (berupa isolasi kertas atau lem kertas).

\section{Kelebihan dan Kekurangan Metode Card Sort}

Yang menjadi kelebihan metode Card Sort adalah:

a. Mudah dilaksanakan.

b. Dapat diikuti oleh siswa yang jumlahnya banyak.

c. Mudah menyiapkannya.

d. Guru mudah menerangkan dengan baik.

e. Siswa lebih mudah mengerti tentang materi yang diajarkan daripada dengan menggunakan metode ceramah.

f. Siswa lebih antusias dalam pembelajaran.

g. Sosialisasi antara siswa lebih terbangun yakni antara siswa dengan siswalebih akrab.

\section{Kekurangan Metode Card Sort}

a. Tidak semua mata pelajaran dapat menggunakan metode Card Sort.

b. Banyak menyita waktu karena menyiapkan model pembelajaran terlebih dahulu.

\section{Metode Card Sort dalam pembelajaran Pendidikan Kewarganegaraan}

Pembelajaran di sekolah yang melibatkan siswa dengan guru akan melahirkan nilai yang akan terbawa dan tercermin terus dalam kehidupan bermasyarakat. Pembelajaran yang melibatkan siswa secara aktif dalam kelompok secara bergotong royong akan menimbulkan suasana belajar partisipasi dan menjadi lebih hidup. Metode Card Sort dalam mata pelajaran PKn dapat mendorong timbulnya gagasan yang lebih bermutu dan dapat meningkatkan kreativitas siswa. Jika pelaksanaan prosedur pembelajaran dengan metode Card Sort ini benar, akan memungkinkan untuk dapat mengaktifkan siswa sehingga dapat meningkatkan prestasi belajar siswa. Sudah saatnya para pengajar mengevaluasicara mengajarnya dan menyadari dampaknya terhadap anak didik. Untuk menghasilkan manusia yang bisa berdamai 
dan bekerja sama dengan sesamanya dalam pembelajaran di sekolah, metode pembelajaran Card Sort perlu lebihsering digunakan karna suasana yang positif akan memberikan kesempatan kepada siswa untuk mencintai pelajaran sekolah atau guru. Selain itu, siswa akan merasa lebih terdorong untuk belajar dan berpikir.

\section{METODE}

Penelitian ini dilaksanakan dikelas V SD Negeri 050748 Pangkalan Berandan dengan jumlah siswa sebanyak 21 orang. Metode penelitian yang digunakan adalah Penelitan Tindakan Kelas (PTK) yang terdiri dari 2 siklus. Siklus I dan II masing-masing terdiri dari perencanaan, tindakan, pengamatan dan refleksi. Data yang digunakan dalam penelitian ini berupa nilai sebagai hasil belajar siswa yang diperoleh melalui tes. Teknik tes digunakan untuk mengukur hasil belajar siswa yaitu dari hasil tes formatif siswa pada siklus I dan siklus II. Tes formatif dilaksanakan padasetiap akhir siklus. Hasil tes formatif siswa juga digunakan untuk menghitungnilai rata - rata kelas dan menghitung tuntas belajar klasikal. Analisis data dilakukan setelah pengumpulan data diperoleh. Berdasarkan data dan hasil pengolahan data yang telah terkumpul, kemudian dianalisis. Indikator keberhasilan ditentukan dari $80 \%$ jumlah siswa SD yang mendapatkan nilai 70 .

\section{HASIL DAN PEMBAHASAN \\ 1. Hasil}

Penelitian tindakan kelas ini dilaksanakan di Sekolah SD Negeri 050748 Pangkalan Berandan tahun ajaran 2016/2017 dengan jumlah siswa 21 orang. Berdasarkan hasil observasi awal, hasil belajar siswa kelas V-A SD Negeri 050748 Pangkalan Berandan tahun ajaran 2016/2017 sangat rendah. Hal itu terlihat dari rendahnya nilai rata-rata yang diperoleh yaitu mencapai 58,57 dengan persentase ketuntasan hanya $19,04 \%$. Setelah tindakan pada siklus I, hasil belajar siswa kelas $\mathrm{V}$-A tersebut mengalami peningkatan. Hal itu terliahat dari meningkatnya nilai rata-rata yang diperoleh mencapai 70,47 dengan persentase ketuntasan $61,90 \%$. Peneliti masih merasa perlu melanjutkan penelitian kesiklus berikutnya karena hasil yang diperoleh masih belum sesuai dengan yang diharapkan. Dilanjukan dengan siklus II, hasil belajar siswa kelas V-A tersebut semakin 
meningkat. Hal itu terliahat dari nilai rata-rata yang diperoleh mencapai 81,42 denga persentase ketuntasan 85,71\%. Hasil ini menunjukkan bahwa hasil yang sudah sesuai dengan harapan peneliti.

\section{Pembahasan}

Berdasarkan hasil observasi awal diketahui bahwa hasil belajar siswa SD Negeri 050748 Pangkalan Berandan tahun ajaran 2016/2017 masih sangat rendah. Hasil belajar tersebut berpengaruh terhadap prestasi belajar siswa dalam pembelajaran PKn. Factor penyebab rendahnya hasil belajar siswa dikarenakan ketidakmampuan siswa untuk mengingat dengan baik materi pembelajaran yang disampaikan oleh guru, selain itu metode yang digunakan guru dalam pembelajaran PKn masih menggunakan metode konvensional yang monoton. Maka dari itu peneliti menggunakan metode baru yang diyakini dapat meningkatkan hasil belajar siswa yaitu dengan menggunakan Metode Card Sort. Setelah diterapkannya Metode Card Sort pada pembelajaran $\mathrm{PKn}$, hasil belajar siswa mengalami peningkatan disetiap siklusnya. Hal itu membuktikan bahwa dengan Metode Card Sort siswa lebih paham dan tertarik untuk mengikuti pembelajaran PKn.

\section{E. SIMPULAN \\ 1. Kesimpulan}

Berdasarkan hasil penelitian dan pembahasan maka dapat disimpulkan bahwa dengan menggunakan metode Card Sort dapat meningkatkan prestasi belajar PKn bagi siswa SD Negeri 050748 Pangkalan Berandan Tahun Pelajaran 2016/2017. Hal ini ditunjukkan berdasarkan nilai rata-rata yang diperoleh dan persentase ketuntasan belajar siswa. Nilai rata-rata yang diperolah siswa pada siklus I mencapai 70,47 dengan persentase ketuntasan $61,90 \%$ dan nilai ratarata yang diperolah siswa pada siklus II mencapai 81,42 dengan persentase ketuntasan $85,71 \%$.

\section{Saran}

Berdasarkan kesimpulan di atas, hal-hal yang sebaiknya di lakukan olehguru dalam pembelajaran agar siswa mencapai prestasi belajar yang memuaskan adalah sebagai berikut: 
1. Sebagai bahan masukan bagi guru dalam melaksanakan pembelajaran khususnya pembelajaran Pendidikan Kewarganegaraan untuk menggunakan metode Card Sort sehingga pembelajaran menjadi lebih optimal dan menyenangkan.

2. Sebelum melaksanakan pembelajaran, sebaiknya guru menyiapkan segala kebutuhan yang diperlukan baik itu metode ataupun media dengan sebaik-baiknya.

3. Kepada guru sebaiknya lebih kreatif dan variatif dalam menggunakan metode pembelajaran. Hal ini akan menghilangkan kejenuhan kepadasiswa selama mengikuti proses pembelajaran.

4. Guru dalam mengajar hendaknya melibatkan siswa secara aktif agar siswamerasa lebih dihargai dan diperhatikan sehingga akan meningkatkan perilaku belajar yang baik.

\section{DAFTAR PUSTAKA}

Depdiknas. 2006. Permendiknas No 22 Tahun 2006 Tentang Standar Isi. Jakarta: Depdiknas

Slameto. 1991. Belajar dan Faktor-faktor yang Mempengaruhi. Jakarta: Rineka Cipta.

Sutikno, S. 2014. Metode dan Model-model Pembelajaran. Lombok: Holistica Lombok.

Syah, M. 2010. Psikologi Belajar. Jakarta: Raja Grafindo Persada. 